\title{
VALIDATION OF THE POSITIVE AND NEGATIVE AFFECT SCHEDULE IN PEOPLE WITH CHRONIC KIDNEY DISEASE
}

\author{
Luís Manuel Mota de Sousa ${ }^{1}$, Cristina Maria Alves Marques-Vieira ${ }^{2}$, Sandy Silva Pedro Severino ${ }^{3}$, Juan Luis \\ Pozo Rosado ${ }^{4}$ Helena Maria Guerreiro José ${ }^{5}$
}

\footnotetext{
${ }^{1}$ Doctoral student in Nursing. Nurse in Hospital Curry Cabral, Centro Hospitalar Lisboa Central EPE, Professor, Universidade New Atlântica. Lisboa, Portugal. E-mail: luismmsousa@gmail.com

${ }^{2}$ Doctoral student in Nursing. Professor, Universidade Católica Portuguesa. Lisboa, Portugal. E-mail: cristina_marques@ics.lisboa. ucp.pt

${ }^{3}$ M.Sc. in Health Management. Nurse in the Hospital Curry Cabral, Centro Hospitalar Lisboa Central EPE. Lisboa, Portugal. E-mail: sandyseverino@gmail.com

${ }^{4}$ Nurse, Hospital Fernando da Fonseca. Lisboa, Portugal. E-mail: juanrosado2009@hotmail.es

${ }^{5}$ Doctoral student in Nursing. Professor, Escola de Saúde Multipefil. Luanda, Angola. E-mail: helena.jose@multiperfil.co.ao
}

\section{ABSTRACT \\ Aim: to analyze the psychometric properties of the Portuguese version of the Positive and Negative Affect Schedule scale in people with chronic kidney disease on hemodialysis. \\ Method: this was a methodological study. A random sample of 171 people chronic kidney disease who receive hemodialysis in two clinics in the region of Lisbon, Portugal. Data was collected from May to June 2015. The psychometric properties were evaluated: Validity (construct, convergent and predictive), reliability (Cronbach's a) and stability (test-retest). \\ Results: showed that the Positive and Negative Affect Schedule scale has two distinct dimensions of positive and negative affect, reliable and stable both when obtained by interview or by questionnaire. \\ Conclusion: the validity and reproducibility of the Portuguese version of the Positive and Negative Affect Schedule scale in people with chronic kidney disease are consistent with the original version and the English version of this scale. \\ DESCRIPTORS: Emotion. Chronic renal insufficiency. Validation studies. Psychometrics. Nursing. \\ VALIDAÇÃO DA POSITIVE AND NEGATIVE AFFECT SCHEDULE EM PESSOAS COM DOENÇA RENAL CRÔNICA}

\section{RESUMO}

Objetivo: analisar as propriedades psicométricas da versão portuguesa da escala Positive and Negative Affect Schedule em pessoas com doença renal crônica em programa de hemodiálise.

Método: tratou-se de um estudo metodológico. A amostra randomizada foi constituída por 171 pessoas com doença renal crônica, submetidas a hemodiálise em duas clínicas na região de Lisboa, Portugal. Os dados foram coletados de maio a junho de 2015. Foram avaliadas as propriedades psicométricas: validade (construto, convergente e preditiva), confiabilidade ( $a$ de Cronbach) e estabilidade (teste-reteste).

Resultados: Permitiram verificar que a escala Positive and Negative Affect Schedule apresenta duas dimensões distintas de afeto positivo e negativo, confiáveis e estáveis, obtidas por entrevista e por questionário.

Conclusão: a validade e reprodutibilidade da versão portuguesa da escala Positive and Negative Affect Schedule em pessoas com doença renal crônica são consistentes com a versão original e a versão portuguesa desta escala.

DESCRITORES: Emoções. Insuficiência renal crônica. Estudos de validação. Psicometria. Enfermagem. 


\section{VALIDACIÓN DE LA POSITIVE AND NEGATIVE AFFECT SCHEDULE EN PERSONAS CON ENFERMEDAD RENAL CRÓNICA}

\section{RESUMEN}

Objetivo: analizar las propiedades psicométricas de la versión portuguesa de la Escala Positive And Negative Affect Schedule en personas con enfermedad renal crónica en programa de hemodiálisis.

Método: este estudio tiene carácter metodológico cuya muestra fue aleatoria y constituida por 171 personas con enfermedad renal crónica que realizan hemodiálisis en dos clínicas de la región de Lisboa. La recogida de datos se realizó entre Mayo y Junio de 2015. Se comprobaron las siguientes propiedades psicométricas: validez (constructo, convergente y predictiva), fiabilidad (a de Cronbach) y estabilidad (teste-reteste).

Resultados: permitieron comprobar que la escala Positive and Negative Affect Schedule presenta dos dimensiones diferentes de afecto; el positivo y el negativo, y que estes se presentan fiables y estables tanto mediante la utilización de entrevista como de cuestionário.

Conclusiones: la validez y reproductibilidad de la versión portuguesa de la escala Positive And Negative Affect Schedule en personas con enfermedad renal crónica son coincidentes con la versión original y portuguesa de la escala.

DESCRIPTORES: Emociones. Insuficiencia renal crónica. Estudios de validación. Psicometría. Enfermería.

\section{INTRODUCTION}

Chronic kidney disease (CKD) is a progressive and irreversible condition characterized by reduced renal function. It is categorized according to the glomerular filtration rate. Treatment depends on the evolution of the disease, which may be conservative, using drugs, the prescription of diets and fluid intake, or can be done with renal replacement therapies, which uses hemodialysis, peritoneal dialysis and kidney transplantation. ${ }^{1}$

This disease affects the patient's renal function and causes physical, psychological and social changes. ${ }^{2}$ The symptoms presented by the patient with CKD include loss of physiological and biochemical functions; bone diseases; anemia; inability to maintain activities and family duties; loss of physical, cognitive and sexual competence; dependence on health care and hemodialysis machines, which can lead to social withdrawal. ${ }^{3}$

Despite treatment with renal replacement therapies, which allow the patient to prolong life and ensure their survival, there are disadvantages, in particular because it affects the performance of activities of daily life, the welfare, the occupation and the quality of life. ${ }^{3-4}$ Affect is an integral part of the patients, being necessary to promote it positively, to ensure well-being. ${ }^{5}$

The Positive and Negative Affect Schedule (PANAS) scale ${ }^{6}$ was developed in order to provide brief, easy to administer and valid measures to assess the positive and negative affects. ${ }^{7}$ PANAS measures the positive affect (PA) and negative affect (NA), which correspond to two general dimensions that describe the emotional experience of individuals. High NA is associated with unpleasantness and subjective to discomfort, which involves emotions like fear, nervousness and disturbance. High PA is associated with pleasure and subjective to well-being, and covers the emotions like enthusiasm, inspiration and determination. ${ }^{6}$

The PANAS can be used as a measurement related to the affective dimension of the concept of subjective well-being, ${ }^{8}$ it has been validated in various cultures and in different languages including, English, German, Turkish, Estonian, Spanish, Russian, Japanese, ${ }^{9}$ in Portuguese ${ }^{7,9}$ European and Brazil ${ }_{10}^{10}$ Indian, ${ }^{11}$ French and ${ }^{12}$ Pakistani and Hungarian. ${ }^{13}$ In the construct validity, the principal component analysis method (PCA) $)^{6-8,13}$ or maximum likelihood ${ }^{10}$ with varimax rotation ${ }^{6,10}$ and confirmatory factor analysis (CFA) was used. ${ }^{12,14}$ The correlation coefficient between the PANAS and anxiety, depression and stress, ${ }^{6}$ and subjective happiness and satisfaction with life in general was used in convergent validity. ${ }^{11}$ Cronbach's a was used in the reliability ${ }^{6-7,10-13}$ and test-retest to assess stability. ${ }^{6}$ In the cultural adaptations, the results have shown good psychometric properties (construct validity, convergent and discriminant). ${ }^{9}$ However, it is important to consider that the semantic translation of emotions is not a univocal process, since there are emotions that can have several possible translations and others have a direct translation, but with multiple and distinct semantic content in different languages. ${ }^{7}$

There is evidence of the importance of subjective well-being in the social context and health, however, little has been explored in patients with CKD in the final stage. ${ }^{16}$

The PANAS scale is validated for the Portuguese population, but not in patients with CKD. Paying attention to the patient with CKD involves complex processes and is emotionally draining ${ }^{3-4}$ it must be verified that the PANAS scale allows 
negative and positive affect measurements and, is reliable and valid for this specific population.

The main question of this research was the following: what are the psychometric properties of the PANAS scale in patients with CKD?

In this sense, the aim of this study is to analyze the psychometric properties of the Portuguese version of the Positive and Negative Affect Schedule scale in people with chronic kidney disease on hemodialysis.

\section{METHOD}

A methodological study was performed, ${ }^{14}$ in two units of the Diaverum Dialysis Clinic in the Lisbon region, between May and June 2015.

The population consists of patients with CKD on hemodialysis. The inclusion criteria were: patients with CKD on hemodialysis for at least six months, and to be 18 years of age or over. Exclusion criteria were: patients with cognitive impairment and active psychiatric illness. Information regarding these conditions of exclusion was obtained through the patient's record.

In total, 253 patients with CKD met the eligibility criteria (139 in Clinic 1 and 114 in the Clinic 2 ). The sample was composed of patients who met the eligibility criteria and their selection was done probabilistically (without random replacement, taking into account the eligibility criteria. The calculation of the sample, with a confidence interval (IC) of $95 \%$ and error sample of $5 \%,{ }^{15}$ recommended a required sample of 192 patients (103 in the Clinic 1 and 89 in Clinic 2). Therefore a random selection without replacement was performed. However, of the patients with CKD selected in the Clinic 1, six patients refused, two were hospitalized and two dropped out, in Clinic 2, four refused to participate, two were admitted to hospital and five gave up. Complete data of 171 patients, 93 (89\%) of Clinic 1 and 78 (88\%) Clinic 2 were obtained at the end.

The following instruments for data collection were used: positive and negative affectivity, the Portuguese version of PANAS, 7 subjective happiness, the Portuguese version of the Subjective Happiness Scale (SHS), ${ }^{16}$ satisfaction with life in general (SWL), the Personal Wellbeing Index (PWI) was used ${ }^{17-01}$ which is a tool for the characterization of the sample profile for sociodemographic and clinical levels (age, gender, nationality, education, occupation, marital status, duration of dialysis, presence of hypertension and diabetes).
The PANAS ${ }^{6}$ scale was adapted and translated for the Portuguese population, ${ }^{7}$ and consists of two subscales: PA and NA, with ten items each, in which constructs are assessed on a Likert scale of 1 to 5 . The respondents were asked to indicate the extent to which they each felt emotions (for each of the 20 items) at the present time. The PA dimension is much more present than the higher score, a maximum of 50 points. The study of the Portuguese version of PANAS revealed just as the original scale, the existence of two factors, internal consistency with Cronbach's a of 0.86 (in the original, $a=0.88$ ) for the positive affection of scale 0.89 (in the original, $\mathrm{a}=0.87$ ) for the negative affect scale and a correlation between the two factors of -0.10 (in the original, $r=0.17$ ). ${ }^{7}$

$\mathrm{SHS}^{18}$ consists of four items; in items two and three the participants were asked to self-characterize themselves compared to their peers in absolute and relative terms. Items one and four correspond to descriptions of happiness and unhappiness. The score of the last item is reversed. On this scale the respondents were asked to indicate the extent to of the statements in self-characterizing, and the answer is given in a visual analogue scale with seven positions, based on two antagonistic statements, which express the level of happiness or lack thereof. The Portuguese version features a single factor with an internal reliability with the value of Cronbach's a of $0.76 .^{16}$

The PWI has been developed from the Comprehensive Quality of Life Scale. It consists of seven items/areas (satisfaction with standard of living, health, personal development, personal relationships, sense of security, connection to the community, and security for the future) that aims to assess satisfaction with life in general. For each statement the respondents are asked to say how satisfied they are with each item/area on a scale from 0 (extremely dissatisfied) to 10 (very satisfied) with a neutral intermediate position. The PWI is calculated on a rating ranging from 0 to 100 (maximum percentage of the scale). The CFA of the English text revealed the existence of a single factor, with an internal reliability with the value of Cronbach's a of $0.81 .{ }^{17}$

Statistical analysis was performed using the Statistical Package for Social Sciences (SPSS) version 20.0. In the evaluation of the psychometric properties, the study of reliability was performed using the Cronbach's a. Additionally, a test-retest was used (after 48 to 96 hours in 40 randomly selected 
patients, 26 questionnaires and 14 interviews) for the evaluation of the stability through the intraclass correlation coefficient (ICC) and the Spearman-Brown correlation..$^{19} \mathrm{~A}$ minimum value of 0.70 was adopted as satisfactory internal consistency. ${ }^{19}$ In the validity study, EFA was the maximum likelihood method with Varimax rotation. The adequacy was assessed by Kaiser-Meyer-Olkin (KMO) and Bartlett's test of sphericity. Convergent validity was assessed by Pearson correlation $(r)$ between the PANAS, the SHS and the PWI. To check the discriminant validity the Student $t$ for independent samples was used, or for ANOVA more than two independent samples was used. Categorical variables were expressed as percentages or absolute value and continuous variables as mean standard deviation or median. Median age and hemodialysis time were used as cut off points to create categorical variables. The significance level was set at $\mathrm{p}<0.05$.

Authorization was requested and granted by the authors of the Portuguese version of the PANAS, ${ }^{7}$ SHS $^{16}$ and PWI. ${ }^{17}$

A support script was created for the completion of the data collection instruments and the training for five nurses was completed. Data collection was performed during the hemodialysis session.

This study was approved by the Ethics Committee of Diaverum (N 1/2015). All participants signed the Informed Consent Term after being informed about the guaranteed confidentiality of data and the right to withdraw without risk to oneself. Privacy was ensured by placing screens or curtains.

\section{RESULTS}

The sample consisted of 171 subjects who met the eligibility criteria, mostly men $(61 \%)$ of Portuguese nationality $(80.1 \%)$, four years of schooling (42.9\%), pensioners $(76.7 \%)$ and married (56.5\%). In which $62.1 \%$ presented arterial hypertension and $27.1 \%$ with diabetes (Table 1 ). In this sample, the mean age was $60.20( \pm 14.34)$ years and receiving hemodialysis for 72.17 ( \pm 54.23$)$ months.

Table 1 - Characteristics of patients with chronic kidney disease evaluated in two clinics. Lisbon, Portugal, 2015. $(\mathrm{n}=171)$

\begin{tabular}{lrr}
\hline Variables & n & $\%$ \\
\hline Gender & & \\
Female & 66 & 38.6 \\
Male & 105 & 61.4
\end{tabular}

\begin{tabular}{lrr}
\hline Variables & n & \% \\
\hline Nationality & & \\
Portuguese & 137 & 80.1 \\
Cape Verdean & 24 & 14.0 \\
Santomense & 6 & 3.5 \\
Guinean & 1 & 0.6 \\
Angolan & 3 & 1.8 \\
Education & & \\
Illiterate & 6 & 3.6 \\
4 years of basic education & 72 & 42.9 \\
6 Year of Education & 31 & 18.5 \\
9 years of Secondary School & 25 & 14.9 \\
12 years of Secondary School & 19 & 11.3 \\
Graduate & 13 & 7.7 \\
Master / PhD & 2 & 1.2 \\
Professional activity & & \\
Retired & 125 & 76.7 \\
Active & 38 & 23.3 \\
Marital status & & \\
Single & 44 & 25.9 \\
Married & 96 & 56.5 \\
Widow(er) & 20 & 11.8 \\
Divorced/separated & 10 & 5.9 \\
Arterial hypertension & & \\
No & 64 & 37.9 \\
Yes & 105 & 62.1 \\
Diabetes & & \\
No & 124 & 72.9 \\
Yes & 46 & 27.1 \\
\hline
\end{tabular}

\section{Reliability and stability}

In the analysis of the psychometric properties, the reproducibility of PANAS, verified by the Cronbach's a coefficient, the PA ranged from 0.84 to 0.87 and NA ranged from 0.86 to 0.88 , after the exclusion each one of the items.

In the stability analysis (test-retest), the data obtained by questionnaire $(n=26)$ showed an overall Cronbach's a in the first assessment of 0.80 and 0.91 in the second evaluation. The Spearman-Brown correlation was 0.91 and the ICC was 0.92 [95\% CI; From 0.88 to $0.96, p<0.001$ ]. Interview $(n=14)$ the overall Cronbach's $\alpha$ in the first assessment was 0.80 and second evaluation was 0.84 . The Spearman-Brown correlation was 0.37 and the ICC was 0.84 [95\% CI; 0.70 to 0.94 , $\mathrm{p}<0.001$, thus consistency and stability between reviews by both self-reported questionnaire and interview was demonstrated.

\section{Validity}

Exploratory factor analysis $(\mathrm{KMO}=0.81$, Bartlett's test of sphericity $\chi^{2}$ [190] 1492.765, 
$\mathrm{p}<0.001)$ showed a single factor solution, which accounted for $48.0 \%$ of the explained variance of the construct. All items were loaded on factors with appropriate factor loadings (ie $>0.3$ ) (Table 2). The Cronbach's a for PA was 0.86 and NA was 0.88 .

Table 2 - Exploratory factor analysis of the Portuguese version of the Positive and Negative Affect Schedule Scale in patients with chronic kidney disease. Lisbon, Portugal, 2015. $(n=171)$

\begin{tabular}{|c|c|c|}
\hline & $\begin{array}{c}\text { Factor } 1 \\
\text { negative } \\
\text { affectivity }\end{array}$ & $\begin{array}{r}\text { Factor } 2 \\
\text { positive } \\
\text { affectivity }\end{array}$ \\
\hline 1. Interested & & 0.504 \\
\hline 2. Disturbed & 0.559 & \\
\hline 3. Excited & & 0.332 \\
\hline 4. Distraught & 0.680 & \\
\hline 5. Pleasantly surprised & & 0.637 \\
\hline 6. Guilty & 0.693 & \\
\hline 7. Shocked & 0.717 & \\
\hline 8. Warm & & 0.543 \\
\hline 9. $\quad$ Repulsed & 0.651 & \\
\hline 10. Enthusiastic & & 0.720 \\
\hline 11. Proud & & 0.620 \\
\hline 12. Irritated & 0.729 & \\
\hline 13. Charmed & & 0.772 \\
\hline 14. Remorseful & 0.653 & \\
\hline 15. Inspired & & 0.764 \\
\hline 16. Nervous & 0.690 & \\
\hline 17. Determined & & 0.686 \\
\hline 18. Trembling & 0.540 & \\
\hline 19. Active & & 0.643 \\
\hline 20. Frightened & 0.659 & \\
\hline Eigenvalue & 5.214 & 4.390 \\
\hline Explained variance & $26.1 \%$ & $21.9 \%$ \\
\hline Coefficient $\alpha^{*}$ & 0.88 & 0.86 \\
\hline Mean (SD †) & $24.7( \pm 8.4)$ & $14.2( \pm 6.1)$ \\
\hline
\end{tabular}

In the study of convergent validity, there was a moderate positive correlation between the scores of PA with SHS and PWI ( $r=0.4$ respectively; $\mathrm{p}<0.001$ and $r=0.33, \mathrm{p}<0.001)$, i.e., high scores on positive affectivity are related to high scores on subjective happiness and satisfaction with life in general. There was a low negative correlation $(r=-0.16, \mathrm{p}<0.001)$ between NA and PWI, i.e. high scores on negative affectivity are associated with lower scores on satisfaction with life in general (Table 3).
Table 3 - Correlations between the Positive and Negative Affect Schedule Scale, subjective happiness, satisfaction with life in general and reliability of measurements in patients with chronic kidney disease. Lisbon, Portugal, 2015. $(n=171)$

\begin{tabular}{|c|c|c|c|c|}
\hline Cronbach's a & PA* $^{*}$ & NAt & SH $\ddagger$ & PWIS \\
\hline PA & 0.86 & & & \\
\hline NA & 0.09 & 0.88 & & \\
\hline $\mathrm{SH}$ & 0.40 ** & $\begin{array}{l}0.09 \\
-0.16\end{array}$ & 0.90 & \\
\hline PWI & 0.33 व & & $0.61 \rrbracket$ & 0.82 \\
\hline
\end{tabular}

*PA: Positive affect; †NA: Negative affect; $¥$ SH: Subjective happiness (SHS); §PWI: Personal wellbeing index; ||<0.05; ๆ $\mathrm{P}<0.01$; ${ }^{* *} \mathrm{p}<0.0001$.

In Table 4, we observe the results of the discriminant validity, in order to identify whether the PA and NA were able to differentiate the variables gender, age, nationality, education, occupation, marital status, presence of hypertension, diabetes and dialysis time. According to the results, the PA cannot discriminate against any of the sociodemographic variables. The NA can only discriminate high blood pressure.

Table 4 - Discriminative validity of the Positive and Negative Affect Schedule Scale in patients with chronic kidney disease. Lisbon, Portugal, 2015. $(n=171)$

\begin{tabular}{lcc}
\hline Variables & $\begin{array}{c}\text { PA* Mean }^{*} \\
\text { (SD } \ddagger)\end{array}$ & $\begin{array}{c}\text { NA† Mean } \\
\text { (SD } \ddagger \text { ) }\end{array}$ \\
\hline Gender & & \\
$\quad$ Male & $24.2 \pm 8.3$ & $14.7 \pm 6.6$ \\
$\quad$ Female & $25.5 \pm 8.5$ & $13.9 \pm 5.8$ \\
Age & & \\
$\quad$ Under 63 years & $25.0 \pm 7.9$ & $15.5 \pm 6.1$ \\
$\quad$ More than 63 years & $24.4 \pm 8.9$ & $13.9 \pm 5.8$ \\
$\quad$ Nationality & & \\
$\quad$ Portuguese & $24.5 \pm 8.2$ & $14.3 \pm 5.8$ \\
$\quad$ another & $25.4 \pm 9.2$ & $13.7 \pm 7.1$ \\
Education & & \\
$\quad$ Below 12 years & $24.2 \pm 8.3$ & $24.2 \pm 8.3$ \\
$\quad$ Than 12 years & $25.5 \pm 8.5$ & $13.9 \pm 5.8$ \\
Professional activity & & \\
$\quad$ Retired & $24.4 \pm 8.5$ & $13.9 \pm 5.6$ \\
$\quad$ Active & $25.7 \pm 8.3$ & $14.2 \pm 7.1$ \\
Marital status & & \\
$\quad$ Single & & \\
$\quad$ Married & $24.2 \pm 8.0$ & $14.5 \pm 6.7$ \\
$\quad$ Other & $24.8 \pm 8.7$ & $14.4 \pm 6.2$ \\
& $25.1 \pm 8.2$ & $12.9 \pm 4.4$
\end{tabular}




\begin{tabular}{lcc}
\hline Variables & $\begin{array}{c}\text { PA* Mean } \\
\text { (SD } \ddagger)\end{array}$ & $\begin{array}{c}\text { NA† Mean } \\
\text { (SD } \ddagger)\end{array}$ \\
\hline Arterial hypertension & & \\
$\quad$ No & $24.7 \pm 7.5$ & $13.7 \pm 4,8 \S$ \\
$\quad$ Yes & $24.8 \pm 8.8$ & $14.3 \pm 6.7$ \\
Diabetes & & \\
$\quad$ No & $25.4 \pm 8.1$ & $14.3 \pm 6.3$ \\
$\quad$ Yes & $22.8 \pm 8.9$ & $13.8 \pm 5.5$ \\
Hemodialysis time & & \\
$\quad$ Less than 60 months & $23.4 \pm 7.9$ & $13.7 \pm 5.9$ \\
$\quad$ Exceeding 60 months & $25.7 \pm 8.8$ & $14.4 \pm 6.3$ \\
\hline
\end{tabular}

* PA: Positive affect, $\uparrow$ NA: Negative affect; $\ddagger$ SD: Standard deviation; $\S<0.05$.

\section{DISCUSSION}

The reliability values are similar to previous versions, ${ }^{6-7,10-11,13}$ except the version of the French and Pakistani samples. ${ }^{12}$ a values obtained in this study are considered good. The test-retest ${ }^{20}$ in the original version was 0.54 for positive affect and 0.45 for negative affect. ${ }^{6}$ In this study the values of the test-retest are greater than 0.7 , which indicates good stability of measurements. ${ }^{20}$

Inconstruct validity, the results of $\mathrm{KMO}$ were similar to the Portuguese of Brazil version $(\mathrm{KMO}=0.89 \%)$, however, the explained variance was lower than the original version $(62.8 \% \text { to } 68.7 \%)^{6}$ and the Portuguese of Brazil (50.05\%). In this study, the KMO values are good and show adequacy of the model to the data. ${ }^{20}$ The factor weights were similar to the original version and Portuguese of Brazil, that is, in the original version ranged from 0.57 to 0.75 for the PA and 0.52 to 0.74 for the NA ${ }^{6}$ and the Portuguese of Brazil version was 0.57 to 0.76 for PA and 0.42 to 0.72 for the NA. ${ }^{10}$ However, item three presents a factor weight of 0.332 which can reveal scale weakness. All items were carried by two factors, like other studies that performed the EFA. ${ }^{6-7,10}$ The CFA held in previous studies in the PANAS and reduced version of PANAS, verified the existence of two factors. ${ }^{8-9,12-14}$

Convergent validity also presented results in the directions expected for PA, ie high scores are associated with high scores of subjective happiness (SHS) and PWI. There was only one negative association with PWI in NA. In the original scale there were correlations between negative affect and anxiety, depression and stress ranging between 0.51 and 0.79 and between positive affect and anxiety, depression and stress ranged from -0.19 to $-0.36 .{ }^{6}$ In a sample study in India, correlations between PA and happiness and life satisfaction varied between 0.18 and 0.44 . The correlation between NA and happiness and satisfaction varied between -0.04 and $-0.16 .{ }^{1}$ Support for external validity of the PA and NA measurements was obtained, similarly to the samples. ${ }^{6,11}$

Only NA can discriminate patients with CKD on hemodialysis based on hypertension, patients with hypertension have higher scores in NA.

The reliability values were similar to the original version, ${ }^{6}$ the versions of European Portuguese ${ }^{7}$ and Brazilian Portuguese. ${ }^{10}$ The PANAS in this sample is reliable and reproducible.

These results are, on the whole, in accordance with the original scale and versions adapted to Portuguese European ${ }^{7}$ and Brazilian Portuguese ${ }^{10}$ suggesting that this is a valid and reliable measure to assess the positive and negative affectivity in patients with CKD.

The limitations are related to data collection, carried out during the dialysis session, which may have influenced the responses, since the technique can sometime cause discomfort to the patient. It is recommended that future research in data collection should be performed prior to the hemodialysis session.

This study used a representative sample of patients with CKD on hemodialysis. In future research it is important to conduct a CFA of this specific population to confirm the structure of the scale, and verify the concurrent validity with measurements of depression, anxiety and stress.

\section{CONCLUSION}

Validation of the Portuguese version of the PANAS in patients with CKD has properties similar to the original scale, to the European Portuguese and the Brazilian Portuguese version.

This study examined the construct validity through exploratory factor analysis, convergent validity with well-being measures and discriminant validity were verified. In addition, the reproducibility of the scale of data collection situation was studied through interviews and author answered questionnaires.

This scale can be used to assess the PA and NA in this specific population, both in the autocompleted questionnaire version and in the interview version.

This is a useful tool which can be used in studies to assess the impact of nursing interventions in people with CKD. 


\section{REFERENCES}

1. Roso CC, Beuter M, Kruse MHL, Girardon-Perlini $\mathrm{NMO}$, Jacobi CS, Cordeiro FR. Self-care of patients in conservative treatment of chronic renal insufficiency. Texto Contexto Enferm [Internet]. 2013 Set [cited 2015 Aug 19]; 22(3):739-45. Available from: http:// dx.doi. org/10.1590/S0104-07072013000300021

2. Knihs NS, Sartori DL, Zink V, Roza BA, Schirmer J. The experience of patients who need renal transplantation while waiting for a compatible organ. Texto Contexto Enferm [Internet]. 2013 Dez [cited 2015 Aug 19]; 22(4):1160-8. Available from: http:/ / dx.doi. org/10.1590/S0104-07072013000400035.

3. Grasselli CDSM, Chaves EDCL, Simão TP, Botelho PB, Silva RR. Avaliação da qualidade de vida dos pacientes submetidos à hemodiálise. Rev Bras Clin Med [Internet]. 2012 nov-dez [cited 2015 Agu 19]; 10(6):503-7. Available from: http://files.bvs.br/ upload/S/1679-1010/2012/v10n6/a3185.pdf

4. Guerra-Guerrero V, Sanhueza-Alvarado O, Cáceres-Espina M. Qualidade de vida de pessoas em hemodiálise crônica: relação com variáveis sociodemográficas, médico-clínicas e de laboratório. Rev Latino-Am Enferm [Internet]. 2012 Sep-Oct; 20(5):838-46. [cited 2015 Aug 19]. Available from: http://www.scielo.br/pdf/rlae/v20n5/pt_04.pdf

5. Galinha I, Ribeiro J. Contribuição para o estudo da versão portuguesa da Positive and Negative Affect Schedule (PANAS): I - Abordagem teórica ao conceito de afecto. Anal Psicol [Internet]. 2005 [cited 2015 Aug 19]; 2(XXIII):209-18. Available from: http:// repositorio.ispa.pt/bitstream/10400.12/179/1/ AP\%2023\%282\%29\%20209-218.pdf

6. Watson D, Clark LA, Tellegen A. Development and validation of brief measures of positive and negative affect: the PANAS scales. J Pers Soc Psychol. 1988; 54:1063-70.

7. Galinha I, Ribeiro J. Contribuição para o estudo da versão portuguesa da Positive and Negative Affect Schedule (PANAS): II - Estudo psicométrico. Anal Psicol [Internet]. 2005 [cited 2015 Aug 19]; 23(2):21927. Available from: http:// publicacoes.ispa.pt/index. $\mathrm{php} / \mathrm{ap} /$ article/viewFile/84/pdf

8. Galinha IC, Pais-Ribeiro JL. The Structure and Stability of Subjective Well-Being: a Structure Equation Modelling Analysis. Appl Res Qual Life [Internet]. 2008 [cited 2015 Agu 19]; 3(4):293-314. Available from: https://www.researchgate.net/ profile/Jose_Pais-Ribeiro/publication/226002463_ The_Structure_and_Stability_of_Subjective_WellBeing_a_Structure_Equation_Modelling_Analysis/ links/00463527e4e2405535000000.pdf

9. Galinha IC, Pereira CR, Esteves F. Versão reduzida da escala portuguesa de afeto positivo e negativoPANAS-VRP: Análise fatorial confirmatória e invariância temporal. Psicologia [Internet]. 2014 [cited 2015 Aug 19]; 28(1):50-62. Available from: http:/ / www.scielo.mec.pt/scielo.php?script=sci_ arttext\&pid=S0874-20492014000100005\&lng=pt\&tl $\mathrm{ng}=\mathrm{p}$.

10. Carvalho HWD, Andreoli SB, Lara DR, Patrick CJ, Quintana MI, Bressan, RA et al. Structural validity and reliability of the Positive and Negative Affect Schedule (PANAS): evidence from a large Brazilian community sample. Rev Bras Psiquiatr [Internet]. 2013 [cited 2015 Aug 19]; 35(2): 169-172. Available from: http:/ / dx.doi. org/10.1590/1516-4446-2012-0957.

11. Singh K, Jha, SD. Positive and negative affect, and grit as predictors of happiness and life satisfaction. J Indian Acad Appl Psychol [Internet]. 2008 [cited 2015 Aug 19];34(2):40-5. Available from: http://medind. nic.in/jak/t08/s1/jakt08s1p40.pdf

12. Karim J, Weisz R, Rehman SU. International positive and negative affect schedule short-form (I-PANAS$\mathrm{SF})$ : Testing for factorial invariance across cultures. Procedia Soc Behav Sci [Internet]. 2011 [cited 2015 Aug 19]; 15:2016-22. Available from: http:// www.sciencedirect.com/science/article/pii/ S1877042811005921

13. Gyollai Á, Simor P, Köteles F, Demetrovics Z. Psychometric properties of the Hungarian version of the original and the short form of the Positive and Negative Affect Schedule (PANAS). Neuropsychopharmacol Hung [Internet]. 2011 [cited 2015 Aug 19]; 13(2), 73-79. Available from: http://www.demetrovics.hu/dokumentumok/ Gyollai_2011_NPPH_panas.pdf

14. Bennett PN, Weinberg MK, Bridgman T, Cummins RA. The happiness and subjective well $\square$ being of people on haemodialysis. J Ren Care. 2015; 41(3):15661.

15. De Lima DVM. Desenhos de pesquisa: uma contribuição para autores. Online Braz J Nurs [Internet]. 2011 [cited 2015 Aug 19]; 10(2). Available from: http://www.objnursing.uff.br/index.php/ nursing/article/view/3648/html

16. Santos GEO. Cálculo amostral: calculadora on-line. [Internet] [cited 2015 May 1]. Available from: http:// www.calculoamostral.vai.la

17. Pais-Ribeiro JL. Validação transcultural da Escala de Felicidade Subjectiva de Lyubomirsky e Lepper. Psicol Saúde Doenças [Internet]. 2012 [cited 2015 Aug 19]; 13(2): 157-168. Available from: http://www.scielo. mec.pt $/$ scielo.php?script=sci_arttext\&pid=S164500862012000200003\&lng=pt

18. Ribeiro JP, Cummins R. O bem-estar pessoal: estudo de validação da versão portuguesa da escala. In: Actas do $7^{\circ}$ Congresso Nacional de Psicologia da Saúde [Internet]. Lisboa: ISPA. 2008 [cited 2015 Aug 19]: 505-8. Available from: http:/ / repositorio-aberto. up.pt/handle/10216/21065

19. Lyubomirsky S, Lepper HS. A measure of subjective happiness: preliminary reliability and construct validation. Soc Indic Res. 1999; 46(2):137-55. 
20. Sousa LMM, Marques-Vieira CMA, Carvalho ML, Veludo F, José, HMG. Fidelidade e validade na construção e adequação de instrumentos de medida.
Enformação [Internet]. 2015 [cited 2015 Aug 19]; 5:2532. Available from: http://www.acenfermeiros.pt/ index.php?id1 $=15 \&$ id2 $=9$ 